\title{
A South American Defence Structure: Problems and Prospects
}

\section{Oscar Medeiros Filho*}

\begin{abstract}
This article discusses the process of building a South American defence architecture over the past two decades, culminating in the formation of the South American Defence Council (Consejo de Defensa Suramericano, or CDS). It discusses the main proposals for a regional security mechanism, primarily made by Brazil and Venezuela, analyses the debates around them, and characterises them as different models of regionalism, namely a pluralistic and amalgamated model. I argue that the differences between these models, and the different agendas underpinning them, constitute obstacles to the progress of regional co-operation and integration in the military field. Other obstacles include the overlap of regional defence initiatives, the different options for operationalising 'extraregional deterrence', the relationship between regional countries and extra-regional actors, the inclusion of security issues in the CDS agenda, and the idea of demilitarising borders.
\end{abstract}

Keywords: South America; Defence; Security; Co-operation; CDS.

\section{Introduction}

A series of initiatives aimed at achieving military co-operation in South America in recent decades culminated in 2008 in the establishment of the South American Defence Council (Consejo de Defensa Suramericano, or CDS).

These initiatives reflect the trend towards regional defence and security arrangements observed in the post-Cold War era, based on the interdependence of states in close proximity to one another. This issue has produced a large volume of literature, with the Theory of Regional Security Complexes (Buzan and Waever 2003) the most prominent perspective. In South America, despite high levels of political instability and social violence, the growth in regional co-operation since the 1990s has led various authors to examine prospects for a security community in the region (Hurrell 1998; Flemes, Nolte and Wehner 2011).

The positive rhetoric of some regional leaders, however, has been contradicted by the lack of capacity for institutionalisation and doctrinal harmonisation necessary for regional co-operation and integration, especially in the fields of defence and security. One of * Centre for Strategic Studies (CEEEx/EME), Brasilia-DF, Brazil; oscarfilho@usp.br. ORCID iD 0000-0002-
2530-7477. 
the reasons for this lack of progress has to do with the undefined preferences for enlarging a regional defence mechanism, given the different 'agendas' of various states in the region (Medeiros Filho 2009; Flemes, Nolte and Wehner 2011). In fact, there are several models of co-operation and integration embedded in the South American regionalisation process that are functionally superimposed. However, the process may still achieve a degree of success (Villa and Bragatti 2015).

Moreover, in recent years, the international context of 'de-globalisation', characterised by the intensification of local (national) strategies, has worked against co-operation and integration initiatives. In this context, regional defence and security initiative also seem tested.

This article seeks to revisit the debate on regional co-operation and integration in the field of defence in South America, focusing on the main 'agendas'1 for and obstacles to the consolidation of the most important regional defence tool, namely the CDS.

To this end, the article is divided into three sections. The first takes up the debate about South America's regional character. The second discusses the origins of and agendas for a regional defence architecture. The third examines factors that may hinder regional defence and security co-operation in South America.

\section{The South American regional character}

In recent decades, many experts have adopted regional analysis in order to study defence and security in South America. In fact, analysing international security issues from a regional perspective has coincided with the 'new wave of regionalism' that began in the mid-1980s and continued after the Cold War. In this period, the intensification of relations among countries at a regional level exposed the need for governance arrangements to manage cross-border flows of people, goods and services, and pointed to the need to create regional blocs.

The regional scale occupies an intermediate space between strictly national perspectives on the one hand, and global perspectives on the other. The value of the regional dimension and the importance given to territorial 'vicinities' are due, in the first instance, to the fact that despite the idea of 'territorial fluidity', which has gained momentum through the process of globalisation, states are geographic entities, and territorial contiguity is still highly relevant in security issues. The permanent location of states is a geopolitical factor that cannot be underestimated. This characteristic presents states with some territorial concerns, notably the fact that they cannot move away from undesirable neighbours.

The idea of regionalising defence and security issues means splitting the global space into a series of regional spaces, with the concept of interdependence playing a central role. In general, 'region' has been understood in International Security studies as a group of interdependent states that, because of geographical imperatives of proximity or neighbourhood, share military threats and concerns, regardless of their other national interests (Buzan 1991).

It is in this sense that we situate South America as a region with a singular nature and singular dynamics. Medeiros Filho (2004) presents four reasons ${ }^{2}$ why South America 
has been defined as a regional spatial area (on a subcontinental scale), beyond the classic Latin American concept. The first is the fact that Latin America, as a 'community', is an exogenous than an autochthonous construction. It is more of a reference to the separation of Anglo-Saxon countries from other American countries than a reference to an international community with a relative degree of integration.

The second reason has to do with various geopolitical imperatives, from issues of terrain (there are no fragmented states or islands in South America) to socio-economic and cultural characteristics (including the greater heterogeneity of Central American and the Caribbean countries). The third reason involves the regional institutional initiatives introduced in recent decades, including Mercosur, the Andean Pact, the Amazon Cooperation Treaty, and, most recently, Unasur and the CDS.

The fourth reason involves the North American hegemonic influence on Mexico and the countries of Central America and the Caribbean, what Buzan and Waever (2003) refer to as 'penetration', which undermines the strategic autonomy of those countries and the establishment of autonomous regional policies about defence and security. These peculiarities confer a specific regional character on the subcontinent.

It also stands out in the international environment ${ }^{3}$ by the absence of classical formal wars in recent years. This has led some authors to argue that South America is well suited to the establishment of a security community. ${ }^{4}$

\section{Defining a security community}

The concept of 'security community' is applied to certain supranational regions that, based on the construction of a collective identity, develop the ability to control their internal conflicts. From a political point of view, a security community can be defined as a supranational region whose member states sustain a real undertaking not to fight against each other (Deutsch 1966: 25). In this perspective, it is possible to imagine the emergence of international spaces in which interstate relations, although anarchic, would not occur in the constant 'shadow of war'. In such a setting, marked by the deliberate ${ }^{5}$ will of member states to build a peaceful environment, the tendency to employ generalised state violence as means of resolving conflicts would be overcome (Adler and Barnett 1998).

Deutsch suggests that security communities should have two levels of integration: amalgamated and pluralistic. The first refers to a much higher level of integration, suggesting the construction of a new political unit, a cohesive bloc, with a common government holding supreme decision-making power. The second and less drastic level of integration refers to a situation in which states remain autonomous units, with their own decisionmaking processes. Security communities can also be defined in terms of their purpose. Thus, for Deutsch:

If the main target of the integration is not only the preservation of peace between the integrated political units, but also the attainment of a major power aiming at general or specific ends, or the attainment of a common functional identity, or even a combination of all 
that, then it is possible that an amalgamated political community with a common government is likely to be the ideal situation. If the main goal is peace, then it is possible that a pluralistic security community be efficient and, in fact, easier to achieve (Deutsch 1982: 269, translation by the author).

Simply stated, then, while a pluralistic community encompasses relations among the members of the region in question (endogenous), an amalgamated community while a supranational construct, also involves relations with third parties (exogenous). Therefore, a pluralistic community is established when the insecurity factors, generated by mutual threats among states in a given region, are overcome. In turn, an amalgamated community, besides resolving the insecurities mentioned above, suggests the adoption of a common defence policy towards state actors outside the region. In this case, it is licit to think about the possibility of forming military alliances.

The distinction between two levels of security community will be resumed in the next section, when the defence and security models conceived for the region will be discussed. In such a theoretical perspective, one of the clearest signs of the emergence of a regional security community would be the overcoming of the notorious 'neighbour-threat' model observed in the context of the Southern Cone, as embodied in the historical disputes between Brazil-Argentina and Argentina-Chile. Nevertheless, the capacity of this 'regional identity' to overcome the conflict among South American countries and sustain the 'birth' of a security community in the region is too subjective and difficult to measure. There are controversies about whether the region is capable of corresponding to the Deutschian typology, and I do not intend to enter into this debate. Instead, I am interested in discussing elements of the narrative consisting of the defence agendas of various states in the region and their bearing on regional defence as a whole, as they have presented themselves empirically in recent decades.

\section{Regional defence architectures: origins and agendas}

Until recently, despite bilateral agreements between some states in the region, the subcontinent lacked regional initiatives that addressed the issues of defence and security, and the idea of a hemispheric architecture dominated by the US persisted (Villa 2007: 22). This only began to change with a series of events ${ }^{6}$ that pointed to a new political-strategic project, breaking with a long Pan-American ${ }^{7}$ tradition, and covered by an interesting geopolitical novelty in South America. Eventually, it resulted in the proposal for a proper South American security arrangement as represented by the CDS. In fact, when compared to other experiences, the early concerns about integration in the areas of defence and security are unique (Villa and Bragatti 2015: 6). The formation of the CDS offers interesting clues to the preferences of various member states and their strategic interests and projects in the region. 


\section{Origins}

The CDS is an outgrowth of the Union of South American Nations (UNASUR). The seeds for its formation were planted when the adoption of joint measures against transnational crimes and greater co-operation in the area of defence were inserted into the topics discussed at meetings of South American Heads of State.

Proposals for establishing the CDS was initially presented during a meeting of Presidents Lula da Silva of Brazil, Hugo Chávez of Venezuela and Néstor Kirchner of Argentina, held at Granja do Torto in Brasília on 19 January 2006. Since its inception, there were two agendas for the project: one Brazilian, and the other Bolivarian. This became clear when the strategic objectives of the new mechanism had to be defined: while Lula advocated the development of a regional defence industry and the establishment of an institutional mechanism for meetings of South American defence ministers, Chavez envisaged the formation of a 'Southern NATO' with a notably anti-hegemonic character.

The process was accelerated from the beginning of 2008 by two events: the attack of Colombian forces on FARC members in Ecuadorian territory, and the reactivation of the US Fourth Fleet operating in the Caribbean and the Atlantic and Pacific Oceans around Central and South America. These events invigorated the debate and promoted a round of negotiations among regional defence authorities, culminating in the establishment of the CDS in December 2008.

\section{Agendas}

Throughout these negotiations, distinctive proposals for a regional defence architecture were evident. Until then, regional interests and preferences which would need to drive a regional defence and security mechanism were relatively undefined. However, three ${ }^{8}$ different 'agendas could be discerned (Medeiros Filho 2009: 11-12): the Bolivarian agenda, based on the socialist and anti-imperialist ideas of then President Hugo Chavez); the Mercosurian agenda, based on liberal ideals linked to the expansion of regional commerce and the maintenance of democratic regimes; and the Brazilian agenda, based on the Brazilian effort to lead the process of regional integration, especially in respect of defence.

These different agendas point to different models of 'regionalism. However, the debate was dominated by the Brazilian and Bolivarian models. The differences between then were clearly exposed in the first round table discussions, as observed by Abdul-Hak:

Brazil argued that the CDS should articulate measures to create and strengthen mutual trust, exchange courses for military personnel and - with particular emphasis - industrial integration in defence. Venezuela highlighted its sense of insecurity when facing extra regional threats, defending a collective defence alliance ('Southern NATO'). Colombia insisted on the treatment, within the framework of a possible CDS, of the fight against drug trafficking guerillas and 
terrorism, among others (Abdul-Hak 2013: 20, translation by the author).

The first document presented to the negotiations, entitled 'Marco Político-Estratégico do Conselho de Defesa Sul-Americano' [Political-Strategic Framework for the South American Defence Council], was introduced by the Brazilian delegation, and presented two main themes: the institutional relevance and attributes of the proposed council (Comini 2015: 118). As regards the first theme - that is, how the new defence mechanism would relate to the existing diplomatic order - it was assumed that it would be subordinate to UNASUR, and would complement, not replace, the other multilateral mechanisms of the Hemispheric and regional systems. In short, it was aimed at avoiding any display of antagonism towards the existing inter-American security structure.

As regards the powers and functions of the proposed body, all the proposals made by the Brazilian delegation were aimed at building an environment of mutual trust, through the creation of channels for dialogue and political co-ordination (Comini 2015: 118). They displayed a clear intention not to create a NATO-type structure on the subcontinent, or any structures with binding powers, such as a 'security council' or a 'multinational force'. In short, Brazil was interested in constructing an environment of 'regional peace', a necessary condition for the country to exercise its regional leadership and international protagonist role.

The second document, presented by the Venezuelan delegation as a counterproposal to the Brazilian suggestion, was entitled 'Estructura propuesta por La República Bolivariana de Venezuela para la conformación del Grupo de Trabajo sobre el Consejo de Defensa Suramericano em el marco de la Unión de Naciones Suramericanas' (Proposal by the Bolivarian Republic of Venezuela for the formation of the Working Group on the South American Defence Council) (Comini 2015: 118). It proposed that the new council should be linked to a military alliance, aimed at the forming a geopolitical power bloc. Such an alliance, based on a 'Bolivarian identity', would be a reaction to the attempted domination of South America by foreign powers. This model of integration was closer to the idea of an 'amalgamated' community, whose main goal would be not only the preservation of peace among the political units making up the region, but also the achievement of greater power, a functional identity, and a common government (Deutsch 1982: 269).

Indeed, the Venezuelan government projected the military dimension of regional integration as part of the consolidation of the Bolivarian project for Latin America. In 2000, Chávez began to advocate the establishment of South American Armed Forces. This idea is also present in Article 3 of the Organic Law of the National Armed Forces of 2005, which authorises Venezuelan armed forces to take part in alliances or coalitions with other armed forces of Latin America and the Caribbean countries (Villa and Bragatti 2015: 13).

While these documents were not definitive, and only presented general outlines, they pointed in opposite directions. The Bolivarian agenda envisaged a strategic regional antiimperialist - that is, anti-American - project, involving the formation of a military alliance. In this perspective, South America was thought of as a compacted bloc, an amalgam- 
ated regional security community with common 'enemies', justifying a common defence, including the establishment of a common military force.

By contrast, the Brazilian agenda sought to move away from the idea of a military alliance, regarding the project as an opportunity for regional co-operation instead. It envisaged a pluralistic and relatively loose alliance in which countries would not form a cohesive defence bloc, but merely co-operate on issues of security.

On 16 December 2008, during a Special Meeting of the Heads of State of Unasur, held in Costa do Sauípe (Bahia, Brazil), the South American Defence Council was created as an advisory body for fostering co-operation and co-ordination in defence affairs. The Brazilian agenda had prevailed, as shown by the three general objectives approved by the meeting: consolidating South America as a zone of peace, thus serving as a base for democratic stability; building a South American defence identity; and building consensus about strengthening regional co-operation in terms of defence.

Besides Brazil's greater material and diplomatic capacity, the Brazilian agenda 'won' due to its more moderate character, which eventually absorbed the more radical approaches proposed by Venezuela (Trinkunas 2013).

\section{Brazil's international agenda}

Brazil's international strategy requires a co-operative and integrated regional space. In this sense, South American integration is a necessity rather than just an opportunity (AbdulHak 2013: 202). In fact, since the late 1970s, Brazilian diplomatic initiatives for fostering regional co-operation have become turning points in South American relations, disassembling the old geopolitics of containment in the process (Villa 2006). As noted by Abdul-Hak, there are numerous factors that promote Brazil's intense regional engagement, including:

[T]he 15791 kilometres of land borders; the massive presence of Brazilian people in neighbouring countries; the porosity of the borders (densely interconnected in the Southern Cone and relatively isolated in the Amazon); the importance of South America as a market for national exports; and the diversification of investments, besides the growing insertion of Brazilian multinationals in neighbouring countries, especially in the energy and engineering sectors (Abdul-Hak 2013: 202-203, translation by the author).

Brazilian attempts to develop a co-operative defence policy in South America began in 1999 with the establishment of the Ministry of Defence, ${ }^{9}$ which amalgamated the previous army, navy and air force ministries. In 2004, for example, during the first year of Lula da Silva's government, the Strategic Affairs Centre (Núcleo de Assuntos Estratégicos, or NAE) in the Brazilian Presidency published a document entitled 'Brasil em 3 Tempos (2007, 2015 e 2022)' (Brazil in three contexts (2007, 2015 and 2022)), which raised the idea of creating a collective defence system with neighbouring countries. 
This serves to illuminate Brazil's role and stance in the CDS negotiations during 2008. ${ }^{10}$ As Abdul-Hak (2013: 240) observes, the eventual mode adopted for the CDS embodied two traditional Brazilian diplomatic goals: the strengthening of interstate co-operation, in order to minimise the risks of having to use military force in its geographical environment; and the consolidation of national and regional autonomy.

However, Brazil's conduct as a regional leader seems erratic. As observed by Spektor (2010: 26), any analysis of Brazil's regional policy should still take into account the country's ambivalence toward surrounding countries: 'Although Brazil encourages the institutionalisation of regional relations, the resulting architecture remains simplistic and relatively weak - mostly because this is what Brazil prefers' (Spektor 2010: 27). This suggests that Brazil has used the regional defence and security project as an opportunity to promote its own interests, and ultimately as a platform for promoting its own projection in the international arena.

Thus, the South American defence and security agenda reveals an ambivalence between the principle of non-intervention and an attitude of non-indifference. ${ }^{11}$ On the one hand, Brazil maintains its own project of regional leadership. On the other, as noted previously, it realises that its international projection also involves accepting elements of regional governance. This institutional layer must be thick enough to protect its national interests, without encumbering Brazilian power or Brasilia’s choices (Spektor 2010: 38).

If the regional defence mechanism remains based on the 'pluralistic' model, it will be interesting to track the extent to which it continues to promote Brazilian strategic interests by allowing the development of a regional capacity of deterrence, building a South American identity of defence, and mitigating regional mistrust, especially in relation to Brazil itself' (Abdul-Hak 2013: 193).

\section{The Bolivarian agenda}

Unlike the Brazilian agenda, which favours a pluralistic model of regionalism without a precise definition of a common ethos (Spektor 2010: 40), the Bolivarian agenda involves a regional identity with clear ideological components, aimed at achieving an amalgamated regional community. According to Villa and Bragatti (2015: 12), the Bolivarian Alliance for the Peoples of Our America (Alianza Bolivariana para los Pueblos de Nuestra America, or ALBA), is also the embryo of the Venezuelan project of regional defence integration. Created in 2004, initially by Cuba and Venezuela, ALBA emerged as a left-wing response to the FTAA (Free Trade Area of the Americas), an attempt to extend the US-dominated North American Free Trade Agreement (NAFTA) to every country in North America, Central America, South America and the Caribbean except Cuba. Indeed, this project is explicitly ideological, and based on the 'Socialism for the $21^{\text {st }}$ Century' of former president Hugo Chavez, merging a socialist, populist, nationalist and, above all, an anti-American bias.

While the Brazilian model has become the backbone of the CDS (Comini 2015), elements of the Bolivarian agenda still persist in current debates within the Centre for Strategic Defence Studies (CEED / CDS). One has to do with the idea of collective defence. 
CEED has sought to promote proposals for a regional defence system as part of a regional strategy for protecting natural resources. According to the initial studies, a future regional defence system should be based on two pillars, namely 'inward co-operation' and 'outward deterrence' (Forti 2013: 15). ${ }^{12}$

The idea of 'outward deterrence' in the narrative developed by the CDS inevitably points to a 'collective defence'. Thus, according to this perspective, 'our regional defence and military capabilities must be concentrated and merged into one' (Forti 2013: 17, translation by the author). Ultimately, the idea of moving towards a regional military alliance and merging South American military capabilities into a 'regional force' reflects the notion of an amalgamated community contained in the Bolivarian agenda.

\section{Obstacles to a regional defence mechanism}

In this section, I present a set of factors that may impede the consolidation of the CDS as a regional defence mechanism.

\section{Between the pluralistic and amalgamated models of regionalism}

The existence of different agendas for regional defence co-operation is an obstacle to its institutionalisation in South America. Brazil and Venezuela are the most important examples. Brazil is interested in a pluralistic, flexible type that advances co-operation, increases trust among regional actors, and creates a safe forum for resolving internal conflicts in the region, provided these mechanisms do not violate the principle of non-intervention.

It is not interested in a military alliance or any collective military instrument (i.e., the 'South American Army' proposed by Chávez, or the 'South American Military Force' suggested by CEED / CDS). This explains why Brazil is reluctant to engage its armed forces in military institutions with elements of supra-nationality in South America (Ferreira 2016).

By contrast, the Bolivarian model involves an amalgamated regionalism based on collective defence, the establishment of a regional alliance, and the formation of a military instrument for regional defence. These are substantial differences, and tend to form barriers to the development of regional defence co-operation in South America.

\section{Overlapping defence initiatives in the region}

As noted previously, the different types of regionalisation observed in South America generate differentiated and competitive initiatives of defence integration. Considering the South American case, Villa and Bragatti (2015) argue that differentiated models of cooperation and integration have resulted in fragmented defence and security institutions that have overlapping functions, and are therefore relatively weak. In their view, the establishment in 2011 of the Centre for Strategic Defence Studies of the CDS (Unasur) as well as the ALBA School of Defence (Escuela de Defensa del ALBA) is one example of such an overlap (Villa and Bragatti 2015: 16). 
The CDS is largely based on the Brazilian model. However, as noted previously, traces of the Bolivarian agenda can also be observed, which works to fragment the regional defence and security project. In this context, the difficulties begin with the very definition of threats, a fundamental element of moving to a 'common regional defence doctrine':

The main threat secured by ALBA is of a classical state nature: the fear of an American invasion. However, this perception of threat is different from the perceptions of UNASUR, which emphasizes multidimensional threats of non-territorial character. Such differentiated perceptions make common strategies difficult for States of both blocs (Villa and Bragatti 2015: 17, translation by the author).

Consequently, regional co-operation in the area of defence is limited to confidencebuilding gestures, which is far from obeying a design consistent with a co-operative process (Saint-Pierre and Palacios Junior 2014: 35). Weakened in this way, the process of institutionalising a regional defence architecture continues, marked by a gap between regionalist rhetoric and concrete co-operation.

\section{Different options for operationalizing 'extra-regional deterrence'}

One of the most original elements of the regionalist narrative that was recently added to the $\mathrm{CDS}^{13}$ framework is related to the idea of 'extra-regional deterrence. ${ }^{14}$ The definition of deterrence at the national level is well-known, and refers to the ability of a state to induce an opponent to give up its alleged intentions by threatening a consequent backlash (Bobbio 2002: 365). However, the extra-regional dimension gives deterrence a new territorial scale: if the targets were neighbours, they are now extra-regional actors. The term 'deterrence' would then be used only to refer to countries that are not on the subcontinent.

While this notion occurs prominently in the Brazilian agenda, the narrative of 'extra-regional deterrence' is based on the idea of a common regional identity, a necessary feature of models of amalgamated integration. Even if one accepts the notion of 'extraregional deterrence' in a pluralistic model, two problems present themselves. The first has to do with the intended recipients of the 'South American deterrence message. The second would be how 'deterrence' could possibly be operationalised at the extra-regional level.

The first problem does not seem difficult to resolve. At face value, any extra-regional political unit (a power or an alliance of countries) that could represent a threat to the territorial integrity of the countries of the subcontinent should be considered potential targets of 'South American deterrence'.

The second problem is more intractable, primarily because adopting a strategy of deterrence inevitably suggests the need to consider a set of resources (means), including the military capabilities needed to implement it. Strategies are of no use without the resources needed to implement them. Ultimately, the most compelling and explicit feature of a deterrence strategy is its military component (Lima 2010: 52).

This is where the problem arises. As noted previously, Brazilian representatives sought from the start of the CDS process to discount any idea of a collective defence body in the 
region. In this context, the idea of regional (or extra regional) deterrence assumes different shapes, depending on the perspective adopted. From a Bolivarian perspective, it would require providing a military component with materiel (hard power). From the Brazilian perspective, however, it would be multidimensional (soft power).

The issue suggested by the Bolivarian agenda is that the efficacy of a regional deterrence strategy has to be supported by a collective defence policy. Above all, there should be a supportive military component. This is explicitly noted in documents produced by CEED / CDS. Indeed, a document entitled 'La Defensa y los Recursos Naturales en Suramérica' (Defence and Natural Resources in South America) clearly expresses itself in favour of establishing a South American Military Force (Forti 2014: 20).

In the Brazilian perspective, 'deterrence' gains another meaning. For example, at the Third Ordinary Meeting of the CDS held in Lima, Peru, on 12 May 2011, then defence minister Nelson Jobim referred to the deepening of the regional co-operation process as a 'factor of extra-regional deterrence. He dismissed the formation of a collective defence organisation like NATO on the subcontinent, but defended the building of a South American defence identity as an extra-regional deterrent.

To summarise, while the Bolivarian agenda requires a military component that would support extra-regional deterrence, the Brazilian agenda involves a much more flexible model, emphasising deterrence as a natural result of the advance of regional co-operation.

\section{Relations between regional countries and extra-regional actors}

Another factor that may impede the more effective integration of the subcontinent are the commercial and military co-operation agreements between UNASUR and more developed countries on other continents. The establishment of 'tacit alliances', such as Venezuela's arms procurement agreement with Russia and China has not always been welcomed by neighbouring states (Flemes, Nolte and Wehner 2011: 105). On the other hand, the US continues to influence relations among South American countries (Sebben 2011: 99). Cooperation agreements between the US and South American states, such as the Colombia Plan, increase distrust among neighbours.

The establishment and maintenance of alternative blocs to UNASUR involving extra-regional countries is another complicating factor. One example is the participation of Venezuela, Ecuador and Bolivia in ALBA, which was formed in 2004. The more recent Pacific Alliance, involving Chile, Colombia, Mexico and Peru, is also a disruptive element in relation to UNASUR, and an obstacle to regional defence proposals.

\section{The incorporation of security ${ }^{15}$ themes into the CDS agenda}

Despite high levels of social violence in South America, and other threats to social stability, ${ }^{16}$ the CDS is restricted to the notion of defence, avoiding other aspects of security, which is almost a paradox given that security in the region is strongly affected by non-state and transnational actors and processes (Villa and Bragatti 2015: 15). There is a great deal of confusion among South American countries on this issue: while some countries can 
tell defence and security issues apart, others cannot, and simply run the two dimensions together. In Argentina, for example, the ideas of defence and 'internal security' are clearly distinct, restricted to the idea of a national effort directed against military aggressions of an 'external nature' (Abdul-Hak 2013: 93). Colombia, on the other hand, under a very different conjuncture, has 'militarized the treatment of its public security', merging the police with the armed forces in a single framework, the Public Forces, as well as its strategies for combating guerrillas (a defence issue) and drug trafficking (a security issue) (Abdul-Hak 2013: 217). It is therefore not surprising that Colombia demanded the explicit inclusion of guerrilla movements as a threat to the region (Versiani et al 2008) in the final text of the CDS founding document.

By contrast, instead of militarising public security issues within the ambit of the CDS, Brazil has proposed the establishment of a subsidiary body under the UNASUR Council of Foreign Affairs Ministers to deal with this dimension (Abdul-Hak 2013: 183).

Regardless of what the CDS prescribes, there are clear differences in the force models adopted by each South American country. In the Andean countries, for example, the military are far more involved in tasks that surpass defence missions. One of these tasks is the maintenance of internal security, prompted by the presence of armed guerrilla groups and their strong connections with international drug trafficking.

However, social violence is not the only factor determining the involvement of armed forces in security affairs; patterns of civilian-military relations also seem to play a fundamental role. In the platinum countries, for example, the idea that military involvement in internal affairs would pose a threat to democracy prevails, since it could result in the militarisation of the public order, increase violence in the fight against crime, and weaken the Rule of Law (Abdul-Hak 2013: 214-215).

In this respect, it is interesting to note that acceptance of military participation in security missions in various South American countries seems inversely proportional to the scars left by military participation in government during the second half of the $20^{\text {th }}$ century. Thus, while in countries that experienced military authoritarianism, such as Argentina and Uruguay, the armed forces are restricted to defence tasks under strong civilian control, in the Andean countries, such as Colombia and Peru, the presence of military personnel in internal missions does not seem to be a major cause for concern.

Therefore, we can conclude that security issues are unlikely to result in co-operative measures if they are addressed within the ambit of defence, especially given the different understandings of governments of the region about involving their armed forces in security issues. As the debate deepens, fissures about threat perceptions and force models should emerge, which could also work to inhibit the process of regional defence co-operation.

\section{Border demilitarisation}

Although border issues persist among countries in the region, ${ }^{17}$ most borders are not insecure in the classic sense. For most South American countries, the main threat would not be the strength of neighbouring states, but the inability of those states to control their border areas, thus allowing the proliferation of transnational threats in those areas. In this 
perspective, the main problems would not be about the frontier - a defence issue - but at the frontier - a security issue (Medeiros Filho 2014: 23). In this case, the logic elaborated by John Herz in the 1950s, namely that strengthening the security of a given state makes its neighbours more insecure, does not seem to apply.

Brazil is a good example. There is not a single frontier problem along its nearly $17000 \mathrm{ki}-$ lometres of borders with neighbouring countries. In fact, the main problem is the porosity of these boundaries, largely caused by geographic factors - sparsely populated, covered by dense forests, and transversely intersected by uncountable navigable rivers. This is underscored by the fact that the Integrated Border Monitoring System (SISFRON) is currently one of the country's most relevant military projects. Despite focusing specifically on combating cross-border crimes, SISFRON is managed by the Brazilian army. This is due to another peculiar characteristic of Brazil: unlike the other countries in the region, it does not have an intermediate security force ${ }^{18}$ (Gendarmerie, Carabineers, National Police or National Guard), which are generally responsible for guarding the frontier. Instead, the Brazilian Army plays a policing role in this area.

The problem is that the simple presence of the military in these areas can increase the suspicions of neighbours. During the first debates sponsored by the CDS, for example, Peru advocated the demilitarisation of national borders, which Brazil found difficult to accept. At that time, the Brazilian attitude was that 'Peru's insistence on disarmament is mistaken, since South America would [then] be the most unarmed region in the world' (Abdul-Hak 2013: 182).

\section{Conclusion}

This study shows that, while some progress has been made towards developing a regional defence and security mechanism, some obstacles persist. Despite its high levels of social violence, positive features of the region are that states spend relatively little on defence; that it is free of chemical and nuclear weapons; and that there were no conventional wars on its territory during the past century.

In general, the process of regional co-operation on defence and security seems to be moving in a positive direction. The formation of the UNASUR Defence Council has been an important step, since it has worked to break down the tradition of hemispheric security blocs and start a countervailing notion of a joint South American defence.

However, differences in perceptions of priority threats and appropriate institutional arrangements persist. The wide spectrum of perceived threats prevents the adoption of a joint defence doctrine or model suited to all the countries of the region. The different institutional solutions sought by various countries to counter the 'new threats', with or without the employment of the armed forces, are in themselves an obstacle to the development of a regional defence identity.

From a military point of view, the establishment of a common defence mechanism for the region as a whole remains a complex issue, largely because of these divergent perceptions emanating from two different agendas (Brazilian and Bolivarian), which have partially conflicting goals. 


\section{Notes}

1 Here, agenda is understood as an ideal model based on discourses and narratives that follow a certain political-strategic pattern in the debate around the goals of the CDS.

2 Considering specifically the narrative of Brazilian External Policy, Spektor (2010: 31-32) presents a more pragmatic reason for the country's choice of belonging to 'South America', to the detriment of the old 'Latin America' label. He believes this option started in the early 1990s as a marketing strategy: it was appropriate for Brazil to distance itself as far as possible from 'Latin America', mainly because of its perception of the negative impact of Mexico (its entry into NAFTA and the consequent 'abandonment' of its strategic autonomy and financial instability) on Brazil's regional interests.

3 There are five possible causes of the low number of wars in the region during the past century: a) its peripheral location in relation to major world conflicts; b) the limited offensive power of countries in the region; c) the hegemonic presence of the US as a stabilising factor; d) priority given to domestic problems ('internal security threats'; and e) the role of standards, given the number of territorial disputes resolved peacefully through arbitration or negotiation (Medeiros Filho 2010: 70-71).

4 According to Adler and Barnett (1998: 49), Security Communities develop in three typical or ideal phases, namely nascent, ascending and mature. The nascent phase is the most basic form of regional integration and the formation of a security community, and corresponds to a growth in channels among the regional countries and the formation of the first regional institutions.

5 The idea of 'political will' in International Relations gives originality to Deutsch's proposal. The concepts of 'security' and 'community' in an international environment are approximated through the identification of values and the possibility of building a common identity. Thus, Deutsch's proposal suggests that the absence of war can be achieved by means other than power, the view held by realists - namely the establishment of a political community.

6 Five notable events were the first meeting of South American presidents (Brasilia, Brazil, September 2000); the Declaration of South America as a Peace Zone (Guayaquil, Ecuador, July 2001); the establishment of the South American Community of Nations (Cuzco, Peru, December 2004); the first meeting of South American Defence Ministers (Bogotá, Colombia, July 2006); and the approval of the South American Defence Council (Bahia, Brazil, December 2008).

7 Abdul-Hak (2013: 39-45) divides the Pan-American movement into four different stages: 1) the classic stage (1889-1933), marked by the projection of military power, especially onto the Caribbean and Central American regions (Corollary Roosevelt); 2) the Policy of Good Neighbourliness (1933-1950), marked by the gradual reduction of military interventionism, the strengthening of economic relations, and the formation of the Inter-American Military System (JID, 1942, TIAR, 1947, OES, 1948); 3) ideological and doctrinal alignments (from 1950 to 1990), marked by the dissemination of the National Security Doctrine; and 4) the post-1990s, marked by the redefinition of the inter-American system and threats to regional security.

8 While Medeiros Filho (2009) identifies three security agendas in UNASUR and the CDS, Flemes, Nolte and Wehner (2011: 117) add a fourth, shared by Colombia, Peru and Chile. This can be characterised as an agenda of security and open autonomy, aimed at complementing and maintaining the channels of dialogue and co-operation with all the countries of the American continent, especially the US and Mexico.

9 In that year, during the ordinary meeting of the Amazon Commission and Regional Development of the Chamber of Deputies on 22 September 1999, then Defence Minister Geraldo Quintão defended the idea of a South American regional strategy capable of reinforcing dialogue about a joint defence policy. He also made it clear that he was not referring to the formation of military alliances in the classical sense.

10 As noted by Abdul-Hak (2013: 77), besides the regional initiatives, Brazil negotiated bilateral defence agreements with all South American countries, except for Venezuela: Argentina (2005), Uruguay (2010), Bolivia (2001), Chile (2007), Peru (2006), Ecuador (2007), Colombia (2008), Guyana (2009), Paraguay (2007) and Suriname (2008).

11 In an address at Beijing University in China on 25 May 2004, then president Lula da Silva declared that the Brazilian government was not only guided by the principle of 'non-intervention', but also by the attitude of 'non-indifference' (Spektor 2010: 28). 
12 As steps towards 'inward' co-operation, Forti mentions the abandonment of old hypotheses of conflict among South American states; the performance of combined exercises; the development of joint doctrines for peace operations, humanitarian assistance, and attention to natural disasters, among others (Forti 2013: 16).

13 Minister Nelson Jobim presented the idea of a common strategy for regional deterrence to the Third Ordinary Meeting of the CDS held in Lima, Peru, on 12 May 2011.

14 The expression 'extra-regional deterrence' appeared for the first time in 2008 in an article entitled 'The scenarios EB/2022 and the Creation of the South American Defence Council', written by Colonel Paulo Roberto Laraburu Nascimento of the Centre for the Army Strategic Studies. The idea was adopted from 2010 onwards in speeches by the then Defence Minister Nelson Jobim as a new pillar of Brazilian defence policy. At the same time, Brazil moved away from a strategy of deterrence towards its neighbours towards a strategy of co-operation.

15 Defence is understood as actions taken by armed forces for guaranteeing the independence, sovereignty and territorial integrity of a country, while security refers to actions taken by police forces in the fight against crime of all kinds.

16 These threats include drug trafficking, organised crime, the smuggling of arms and people, the presence of insurgent guerrilla or paramilitary groups, and urban violence (Villa and Bragatti 2015: 15).

17 Chile versus Peru; Chile versus Bolivia; Venezuela versus Colombia; and Venezuela versus Suriname, among others.

18 Although Article 144 of the Federal Constitution assigns border policing to the Federal Police, the extent of Brazil's borders and the limited number of police officers assigned to these areas require the participation of the armed forces.

\section{References}

Abdul-Hak, Ana P N. 2013. O Conselho de Defesa Sul-Americano: objetivos e interesses do Brasil. Brasilia: FUNAG.

Adler, Emanuel and Michael Barnett. 1998. Security Communities. New York: Cambridge University Press.

Bobbio, Norberto. 2002. Dicionário de Política. Vol. 1. Brasilia: UnB.

Buzan, Barry. 1991. People, States and Fear: An Agenda for Security Studies in the Post-Cold War Era. London: Wheatsheaf.

Buzan, Barry and Ole Waever. 2003. Regions and Powers: the Structure of International Security. Cambridge: Cambridge University Press.

Comini, Nicolás. 2015. 'El origen del Consejo de Defensa Suramericano: Modelos en pugna desde una perspectiva argentina’. Revista de Estudios en Seguridad Internacional, 1 (2): 109-135.

Deutsch, Karl W. 1966. Integracíon y Formacion de Comunidades Politicas: análisis sociológico de experiencias históricas. Transl. Lilia Gaffuri. Buenos Aires: INTAL.

. 1982. Análise das relações internacionais. Transl. Alcides Gastão Rostand Prates. Brasilia:

UnB.

Ferreyra, Matias D A. 2016. 'As Forças de Paz Combinadas Sul-Americanas e o descompasso brasileiro: o caso da Brigada Binacional "Cruz Del Sur". Paper delivered at IX ENABED, Florianópolis, Brazil, 6-8 July 2016.

Flemes, Daniel, Detlef Nolte and Leslie Wehner. 2011. 'Una Comunidad de Seguridad Regional en formación: la UNASUR y su Consejo de Defensa'. Estudios Internacionales, 170: 105-127. 
Forti, Alfredo W. 2013. 'El papel de la Defensa en una Estrategia Suramericana para el Aprovechamiento de los Recursos Naturales'. Paper delivered at conference entitled 'Visiones hacia una Estrategia Suramericana para el aprovechamiento de los recursos naturales'. Caracas, Venezuela, 27-30 May 2013.

2014. 'La Defensa y los Recursos Naturales en Suramerica: Aportes para una Estrategia Regional'. Paper delivered at conference entitled 'Defensa y Recursos Naturales' [Defence and Natural Resources]. Buenos Aires, Argentina, 9-10 June 2014.

Hurrell, Andrew. 1998. 'Emerging Security Community in South America?' In Emanuel Adler and Michael Barnett (eds), Security Communities. Cambridge: Cambridge University Press, pp. 228-264. Lima, Reinaldo Nonato de Oliveira. 2010. 'Faces de Estratégia da Dissuasão'. Revista Padeceme, 22. Rio de Janeiro: ECEME.

Medeiros Filho, Oscar. 2004. Cenários geopolíticos e emprego das Forças Armadas na América do Sul. Masters Thesis. University of São Paulo.

2009. 'Conselho de Defesa Sul-americano: Origens, Demandas e Propósitos.' Paper delivered at III ENABED. Londrina, Brazil, 28-30 July 2009.

2010. Entre a cooperação e a dissuasão: políticas de defesa e percepções militares na América do Sul. PhD Thesis. University of São Paulo, Brazil.

2014. 'Breve panorama de segurança na América do Sul.' In: Reginaldo Mattar Nasser,

Rodrigo Fracalossi de Moraes (eds), O Brasil e a segurança em seu entorno estratégico. Brasilia: IPEA, pp. 21-42.

Neto, Álvaro P and Giovanni H C Okado. 2013. 'A corrida armamentista sul-americana: realidade ou falácia?' Revista da Escola de Guerra Naval, 19 (2): 463-484.

Saint-Pierre, Héctor L and Alberto M C Palacios Junior. 2014. 'As medidas de confiança no Conselho de Defesa Sul-americano (CDS): análise dos gastos em Defesa (2009-2012)'. Revista Brasileira de Política Internacional, 57 (1): 22-39.

Sebben, Fernando Dall'Onder. 2011. 'América do Sul: comunidade de segurança ou paz violenta?' Relações Internacionais no Mundo Atual, 2 (14): 48-78.

Trinkunas, Harold. 2013. 'Reordering Regional Security in Latin America' Journal of International Affairs, Spring/Summer: 83-99.

Versiani, Isabel, Julio Villaverde, Raymond Collit and Mair Pena Neto. 2008. 'Unasul nasce mas Colômbia não apóia Conselho de Defesa'. O Estado de S. Paulo, 23 May 2008. At http://g1.globo. com/Noticias/Mundo/0,,MUL534554-5602,00-UNASUL+NASCE+MAS+COLOMBIA+NAO+AP OIA+CONSELHO+DE+DEFESA.html. [Accessed on 21 May 2017].

Villa, Rafael Duarte. 2006. 'Política externa brasileira: capital social e discurso democrático na América do Sul'. Revista Brasileira de Ciências Sociais, 21 (61): 63-89.

2007. Quatro teses sobre a política de segurança dos Estados Unidos para a América do Sul. PhD Thesis, University of São Paulo.

Villa, Rafael Duarte and Milton Carlos Bragatti. 2015. 'Complexificação das Instituições de defesa na América do Sul'. Revista Carta Internacional, 10 (3): 4-22.

Wendt, Alexander. 1999. Social Theory of International Politics. Cambridge: Cambridge University Press. 


\section{Disclaimer}

The views expressed in this article are those of the author in his personal capacity and do not necessarily reflect those of the Brazilian Army.

\section{About the author}

Oscar Medeiros Filho is an Army Officer. He holds a Master's degree in Human Geography and a PhD in Political Science from the University of São Paulo (USP), Brazil. He currently co-ordinates research at the Centre for Strategic Studies of the Army (CEEEx/ EME). Previously, he taught Geography, Sociology and Politics at the Preparatory School for Cadets of the Brazilian Army; International Relations and Geography at the Military Academy of Agulhas Negras; and Geopolitics at the Meira Mattos Institute of the Army Command and General Staff College.

\section{Uma Estrutura de Defesa da América do Sul: Problemas e Perspectivas}

Resumo: Este artigo discute o processo de construção de uma arquitetura regional de Defesa na América do Sul ao longo das duas últimas décadas e que acabou por constituir o Conselho de Defesa Sul-americano (CDS). Discute-se as principais propostas de um mecanismo de segurança regional, apresentadas sobretudo pelo Brasil e a Venezuela, analisando os debates em torno deles e caracterizando-os como diferentes modelos de regionalismo, a saber, um modelo pluralístico e amalgamado. Argumento que as diferenças entre esses modelos e as diferentes agendas e eles subjacentes constituem obstáculos ao progresso da cooperação regional e da integração no campo militar. Outros obstáculos incluem a sobreposição das iniciativas de defesa regional, as diferentes opções de operacionalizar a ideia de "dissuasão extra-regional", a relação entre países da região e atores extra-regionais, a inclusão de questões de segurança na agenda do CDS e a ideia de desmilitarização de fronteiras.

Palavras-chave: América do Sul; Defesa; Securança; Cooperação; CDS.

Received on 14 December 2016, and approved for publication on 25 April 2017.

\section{(cc) BY-NC} https://creativecommons.org/licenses/by-nc/4.0/ 